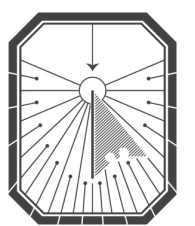

KYIV-MOHYLA HUMANITIES JOURNAL

KYIV-MOHYLA SCHOLARLY PEER-REVIEWED JOURNALS

Post-Communist Institution-Building and Media Control

Author(s): Natalya Ryabinska

Source: Kyiv-Mohyla Humanities Journal 7 (2020): 73-100

Published by: National University of Kyiv-Mohyla Academy

http://kmhj.ukma.edu.ua/ 


\title{
Post-Communist Institution-Building and Media Control
}

\author{
Natalya Ryabinska \\ Collegium Civitas (Warsaw), \\ Sociology Department
}

\begin{abstract}
This study uses an interdisciplinary perspective to shed light on Ukraine's continuous problems with media independence, which to date have not allowed Ukraine to become a country with a truly free media: since Ukraine's independence in 1991 its media have consistently remained only "partly free." ${ }^{1}$ The approach proposed in the paper combines theoretical tools of post-communist media studies with advancements in political science research in regime change and state-building to explore the continuities and changes in the institutional environment for the media in post-communist new democracies. The approach is applied to analyze two cases of post-communist media change, both problematic to explain within the framework of media studies alone: the case of incomplete media transformation in a hybrid regime (Ukraine) and the incident of backsliding in independent media in an advanced new democracy (Hungary).

The paper is structured as follows: I first present the shortcomings in the way institutions, or more specifically the institutional environment for media freedom, were previously approached in post-communist media studies. I then propose a more advanced approach based on theories and concepts originating from comparativepolitics studies of regime change and state and institution-building. I apply this approach to analyze the institutional environment for the media in Ukraine. Next, I explore the case of a radical reconstruction of media-related institutions in Hungary after Viktor Orbán's Fidesz party came to power in 2010.
\end{abstract}

Key Words: Post-communist, media, enabling environment, institution-building, Ukraine.

\section{(7)}

In early studies of media transformations in former socialist states in Central and Eastern Europe and Eurasia, researchers were mostly concerned with whether institutions necessary for safeguarding the independence of the media were introduced in these states at all. ${ }^{2}$ Once a new institutional framework for the media was established, the

$1 \quad$ “Freedom of the Press. Ukraine," 1994-2017, Freedom House, accessed June 20, 2020, https:// freedomhouse.org; "Freedom in the World. Ukraine," 1992-2019, Freedom House, accessed June 20, 2020, https://freedomhouse.org. on Media Independence and Pluralism, eds. Sandra Hrvatin and Brankica Petković (Ljubljana: 
researchers' interest in media-related institutions decreased, as it was assumed that now a more important issue to analyze was the implementation, or even proper operation of laws, and, generally, the alignment of people's attitudes and behavioral patterns to the new media regulations. ${ }^{3}$ It is this delineation that made media independence, which was believed to be a major sign of the consolidation of media freedom, to use Larry Diamond's words, "the only game in the town." However, the picture of institutional change regarding the media in post-communist Europe and Eurasia appeared to be much more complex. ${ }^{4}$ Not only did the formal institutional frameworks undergo frequent change, much too often to the detriment of media independence and pluralism, they also influenced media not on their own, but together with various informal institutions - again, often weakening or damaging media freedom. This was not properly reflected in the theoretical approaches used to investigate the role of institutions in media change in the region.

One of the basic weaknesses of the media studies approach to the institutional framework for media freedom in new democracies of Central and Eastern Europe and the former Soviet Union in media studies was that it was static. More specifically, it concentrated on the results of institution-building (which, however, too often appeared to be open to subsequent change) without closer attention to the process of institutionbuilding and its regularities. Most often, scholars made "snapshot evaluations" of the countries' media regulatory frameworks from the point of view of their correspondence to democratic standards. When major institutions for safeguarding media freedom were established in a country, the attention of media scholars shifted away from the institutions. It was assumed that after the introduction of new press and media laws and regulatory structures the process of media democratization continues to occur predominantly in the cultural and behavioral dimensions, where norms, values, attitudes, and behavior patterns are harmonized with the base line of media freedom. However, as time went on, actual processes deviated from this model of media transformation. First, in many cases (especially in former Soviet republics) clauses necessary to ensure press freedom were poorly designed - for example, they could contain built-in loopholes or limited provisions for enforcement. This leveled their effect for safeguarding press freedom and gave incumbents an opportunity to interfere with the media. Second, the

SEENMP and Peace Institute, 2004), 12-17; Andrei Richter, "The Partial Transition: Ukraine's Post-communist Media," in Media Reform: Democratizing the Media, Democratizing the State, eds. Monroe Price, Beata Rozumilowicz, and Stefan Verhulst (London: Routledge, 2002), 133-37; Peter Gross, Entangled Evolutions: Media and Democratization in Eastern Europe (Washington, D.C.: Woodrow Wilson Center Press, 2002), 72-79.

See, for example, Peter Gross, "Between Reality and Dream: Eastern European Media Transition, Transformation, Consolidation, and Integration," East European Politics and Societies: and Cultures 18.1 (2004): 110-31, https://doi.org/10.1177/o888325403259919. 
new media regulations occurred to be anything but stable. ${ }^{5}$ In many of them changes in media legislation occurred on a regular basis, often resulting from ad hoc needs of the powers that be. ${ }^{6}$ In some instances these changes were evidently harmful for media independence, as in the case of Orbán's Hungary since 2010, or Poland under the rule of the right-wing Law and Justice (PiS) party since 2015. This all showed that even three decades after the beginning of the transformations the institutional environment for the media may undergo change. This requires that media scholars in new democracies problematize not only the effects of institution-building in these countries' media realm but also the processes by which these institutions come into being and into action and, possibly, undergo subsequent change.

The next weakness in approaching institutions in post-communist media studies may be defined in terms of the adherence to the so-called transition paradigm. ${ }^{7}$ The analysis of institutions here was most often purposed at estimating to what extent (if any) did the newly introduced institutional and regulatory structures, such as media laws and regulatory bodies, correspond to democratic norms (or, in case of EU newcomers, to European Union media policy and regulations). This presupposed that these institutions are only an imperfect version of democratic ones, to be improved in the process of further democratization. This way of thinking de facto drove research into the framework of the so-called "transition paradigm," which assumes that transitional societies move in a linear way in a predetermined direction, namely towards democracy. The cases of sharp deterioration in media freedom in countries classified as consolidated democracies (like Poland and Hungary) as well as non-linear media change in some FSU and Balkan states (semi-consolidated democracies or hybrid regimes) show that this way of thinking has its limitations. It can possibly be helpful when focusing on democratization, but fails to explain movement in the opposite direction.

Finally, media studies research devoted to institutions as a rule focused on formal institutions and structures without considering informal ones. This reduced the explanatory power of these studies because as some investigations have demonstrated, the relationships between the media and politics in post-communist countries are commonly regulated less by formal, but more by informal rules. ${ }^{8}$ In several studies

Martin Krygier, “Good, Bad, and 'Irritant' Laws in New Democracies,” in Media and Politics in New Democracies: Europe in a Comparative Perspective, ed. Jan Zielonka (Oxford: Oxford University Press, 2015), 119-36; Nikola Belakova and Silvana Tarlea, How National Parliaments Legislate the Media in CEE: The Adoption and Implementation of Media Legislation in the Czech Republic, Romania and Slovakia (Oxford, 2013), accessed September 18, 2014, http://mde. politics.ox.ac.uk/images/stories/documents/mdcee\%2olegislative\%2oreport_ro-cz-sk_pv.pdf.

6 Paolo Mancini, “The News Media Between Volatility and Hybridization," in Media and Politics in New Democracies: Europe in a Comparative Perspective, ed. Jan Zielonka (Oxford: Oxford University Press, 2015), 27-28.

A term introduced by Thomas Carothers in: Thomas Carothers, "The End of the Transition Paradigm," Journal of Democracy 13.1 (2002): 6-9, https://doi.org/10.1353/jod.2002.0003.

8 Barbara Pfetsch and Katrin Voltmer, "Negotiating Control," The International Journal of Press/ Politics 17.4 (2012): 388-406, https://doi.org/10.1177/1940161212449o84; Natalya Ryabinska, 
that took into consideration also informal institutions, the latter were approached as cultural phenomena. Thus the persistence of informal regulations in mediapolitics relationships in the region was attributed to the remnants of the political culture inherited from the communist (and even pre-communist) past. However, as the studies on formal and informal institutions in political science demonstrate, ${ }^{9}$ 1) informal institutions are not necessarily rooted in cultural traditions (and many have nothing to do with culture), 2) being "socially shared rules, usually unwritten, that are created, communicated, and enforced outside of officially sanctioned channels," they are not necessarily self-enforcing, but can be enforced externally (for example by state bodies engaged in organized state corruption), ${ }^{10} 3$ ) there are some external conditions - such as the persistence of external enforcement mechanisms - that may stipulate the durability of informal rules. Indeed, as Grethen Helmke and Steve Levitsky point out, informal institutions may weaken or collapse due to changes in the formal institutional environment, for example, with the rise in the level and effectiveness of the enforcement of formal rules, which the informal ones substitute or compete with. ${ }^{11}$

What can help to overcome the above shortcomings in approaching institutions in post-communist media studies is first and foremost taking a perspective that sees the institutions through the prism of the process of state and institution-building (or, more often lately - institution modifying or even refashioning). This can be found in studies on post-communist state-building that highlight the processes by which states (and institutions) come into being and into action. ${ }^{12}$ According to Anna GrzymalaBusse and Pauline Luong, the critical mechanism underpinning the creation of state

Ukraine's Post-Communist Mass Media: Between Capture and Commercialization (Stuttgart:

Ibidem-Verlag, 2017), 75-77.

9 See: Gretchen Helmke and Steven Levitsky, "Informal Institutions and Comparative Politics:

A Research Agenda," Perspectives on Politics 2.4 (2004): 725-40, https://doi.org/10.1017/

S1537592704040472.

10 Helmke and Levitsky, "Informal Institutions," 727.

$11 \quad$ Helmke and Levitsky, "Informal Institutions," 732.

12 Venelin Ganev, "Post-Communism as an Episode of State Building: A Reversed Tillyan

Perspective," Communist and Post-Communist Studies 38.4 (2005): 425-45, https://doi.

org/10.1016/j.postcomstud.2005.09.0o8; Venelin Ganev, Preying on the State: The Transformation

of Bulgaria after 1989 (Ithaca: Cornell University Press, 2007); Anna Grzymala-Busse, "Post-

Communist Competition and State Development," Program on Central \& Eastern Europe

Working Paper Series no. 59 (2004); Anna Grzymala-Busse, Rebuilding Leviathan Party

Competition and State Exploitation in Post-Communist Democracies (Cambridge: Cambridge

University Press, 2007); Anna Grzymala-Busse and Pauline Jones Luong, "Reconceptualizing

the State: Lessons from Post-Communism," Politics \& Society 30.4 (2002): 529-54, https://

doi.org/10.1177/oo3232902237825; Anna Grzymala-Busse and Pauline Jones Luong,

"The Peculiarities of Post-Communist State Development: Institutional Consolidation and Elite Competition," in The Oxford Handbook of Transformations of the State, eds. Stephan Leibfried,

Evelyne Huber, Matthew Lange, Jonah D. Levy, and Frank Nullmeier (Oxford: Oxford University

Press, 2015), 587-6o1; Serhiy Kudelia, "The Sources of Continuity and Change of Ukraine's 
institutions in post-communist Central and Eastern Europe (CEE) and Former Soviet Union (FSU) countries is elite competition. ${ }^{13}$ Specifically, it is "elite competition over the authority to create the structural framework through which policies are made and enforced." ${ }^{14}$ As studies on post-communist institution-building demonstrate, one of the elites' fundamental goals in the creation of this structural (or institutional) framework is to minimize constraints for their discretion, where discretion is understood as an unregulated and unmonitored use of state resources for private ends..$^{15}$ In pursuit of this goal, the elites engaged in institution-building pay special attention to institutions that constrain their discretionary access to state resources, in particular formal institutions of oversight and regulation, such as national accounting offices, security and exchange commissions, government procurement regulations, or laws regulating party financing. ${ }^{16}$

Because the above institutions significantly constrain the discretion of incumbents to extract state resources for private ends, incumbents may sabotage their creation. According to Grzymala-Busse, avoidance or at least postponing the emergence of discretion-limiting institutions is one of the three ways in which ruling elites can build discretion into post-communist formal institutional frameworks: the absence of regulation in a particular realm creates favorable conditions for incumbents to abuse their power and exploit the state in this realm. ${ }^{17}$ The two other ways to build discretion in institutional frameworks are, first, the construction of winner-take-all or winner-takemost institutions, and, second, the creation of lax or unenforced formal institutions. ${ }^{18}$ In the first case, the institutions are designed in such a way that they privilege the government or party of the day and give them considerable discretion (e. g. by leaving the power of appointment to these institutions in the hands of the president or prime minister, or by introducing parity with the distribution of seats in parliament, giving the ruling party/coalition an automatic majority in a collective body). In the second case, the discretion-limiting institutions are deliberately designed to be lax or unenforced, so that they cannot serve as strong safeguards against potential power abuses. They are often characterized by ambiguous language, loopholes, and limited provisions for enforcement. ${ }^{19}$

Incomplete State," Communist and Post-Communist Studies 45·3-4 (2012): 417-28, https://doi. org/10.1016/j.postcomstud.2012.06.oo6. Grzymala-Busse and Luong, "Reconceptualizing the State," 531.

14 Grzymala-Busse and Luong, "Reconceptualizing the State," 531.

15 Grzymala-Busse, "Post-Communist Competition”; Grzymala-Busse, Rebuilding Leviathan; see also Ganev, Preying on the State; Kerstin Zimmer, "Formal Institutions and Informal Politics in Ukraine," in Formal Institutions and Informal Politics in Central and Eastern Europe: Hungary, Poland, Russia and Ukraine, ed. Gerd Meyer (Opladen; Farmington Hills: Barbara Budrich, 2008), 267-303.

16 Grzymala-Busse, "Post-Communist Competition," 5.

17 Grzymala-Busse, "Post-Communist Competition," 3.

18 Grzymala-Busse, "Post-Communist Competition," 3. 
The above state and institution-building approach can be useful for analyzing the institutional environment for the media in new democracies. We can assume that the same incentives that guide post-communist institution builders concerning the creation of (or the avoidance to create) institutional constraints on the exercise of their power may also work in building the institutions regulating mass media and assumed to safeguard press freedom. As Karol Jakubowicz pointedly noted in his analysis of media freedom in post-communist political systems, "because of the importance of the media, political elites... seek to retain as much of discretionary power over the media as possible and to accept as few effective restraints of their power as possible." 20 Indeed, the enormity of the battles fought over institutions regulating and controlling media in post-communist legislatures suggests they certainly mattered (and continue to matter) to post-communist political actors.

According to recent studies on post-communist state development, early postcommunist state-building had significant implications for political regimes in CEE and FSU countries. ${ }^{21}$ Once adopted, state institutions started to function as either those that protect the gains of early winners of elite competition, or those that create guarantees for the losers of this competition. ${ }^{22}$ We can speak, correspondingly, about two kinds of states that have emerged out of the ashes of the communist states: winner-take-all states and power-sharing states. As Grzymala-Busse and Luong specify, in the first case (characteristic of many former Soviet republics) the effect of the initial institutionbuilding after the fall of communism was the rise of state institutions that tended to entrench the gains of incumbents at the expense of their opponents. ${ }^{23}$ Conversely, in much of CEE the newly shaped state institutions did not a priori entrench a given set of winners, and instead provided a slew of institutional guarantees for losers. These guarantees resulted in a much broader and malleable pool of elites that flow in and out of state positions as they compete for popular support rather than proximity to power. ${ }^{24}$

The above does not mean, however, that the process of institution-building in post-communist Europe and Eurasia is over in the sense that its outcomes are stable. The spectacular episode of institutional transformation in Hungary after 2010 as well as other, though rare, cases of radical state institution reconstruction in the region exemplify, according to the pointed observation by Grzymala-Busse and Luong, "the continuation of elite efforts to target institutions to favor themselves." ${ }^{25}$

Karol Jakubowicz, "Post-communist Political Systems and Media Freedom and Independence," in Central and Eastern European Media in Comparative Perspective: Politics, Economy and

Culture, eds. John Downey and Sabina Mihelj (Burlington: Ashgate, 2012), 34.

Grzymala-Busse and Luong, "Peculiarities," 588-92; Milada Anna Vachudova, “The

Transformation of the State in Eastern Europe," in The Oxford Handbook of Transformations

of the State, eds. Stephan Leibfried, Evelyne Huber, Matthew Lange, Jonah D. Levy, and Frank

Nullmeier (Oxford: Oxford University Press, 2015), 6о3-04.

Grzymala-Busse and Luong, "Peculiarities," 588-89.

23 Grzymala-Busse and Luong, "Peculiarities," 588-89.

24 Grzymala-Busse and Luong, "Peculiarities," 599.

Grzymala-Busse and Luong, "Peculiarities," 590-91. 


\section{The Contexts of Media Change in Ukraine and Hungary}

Ukraine is one of the cases of incomplete media transformation in FSU hybrid regimes. Though Ukraine managed to escape the fate of Russia or Belarus, whose authoritarian rulers consistently curbed media independence thereby bringing about "unfree" media systems, its media have never become "free" either, remaining for most of Ukraine's independence only "partly free." 26 The trajectory of Ukraine's media change since 1991 resembles a sinusoid: from increased media freedom in the first years of transformation in the early 199os through a severe regression during Leonid Kuchma's second presidency (2000-2004) and a decided improvement after the Orange Revolution in 2004, to another deterioration during the Yanukovych era (2010-2014), after which significant positive developments in the realm of media freedom occurred in postMaidan years (2014-2019). Still, the positive changes in media regulation introduced in Ukraine after Yanukovych's ouster in 2014 were insufficient to complete the country's media reform and the media continued to face many of the problems they experienced before: in-house censorship, impunity for crimes against journalists, and the use of the media by politically engaged business tycoons for their political purposes. ${ }^{27}$

Since 2014 a significant factor in Ukraine's media policy is Russia's hybrid warfare in Ukraine, especially its informational component. Seeking to counter Russian propaganda the Ukrainian government took a series of measures, such as blocking Russian TV channels or banning Russian social media networks VKontakte and Odnoklassniki. These measures were negatively assessed by many international humanrights and media-protection organizations, ${ }^{28}$ whereas the reaction to them from the Ukrainian media and tech community was mixed. For example, among one hundred and twelve experts from the media, human rights, and IT sectors asked by Internews Ukraine about their opinion on the ban of Russian social networks in October 2017, $56 \%$ replied that it was a strategically sound decision. ${ }^{29}$

26 "Freedom of the Press. Ukraine;" "Freedom in the World. Ukraine," 1992-2019, Freedom House, accessed June 20, 2020, https://freedomhouse.org.

"Freedom of the Press. Ukraine," 2017; "Freedom in the World. Ukraine," 2018-2019; "Media Sustainability Index. Europe and Eurasia: Ukraine," 2018, 2019, International Research \& Exchanges Board, accessed August 13, 2020, https://www.irex.org/resource/mediasustainability-index-msi\# europe-eurasia.

28 Concerns were expressed by organizations including Human Rights Watch, Reporters Without Borders, the Committee to Protect Journalists (CPJ), the European Federation of Journalists (EFJ), and the Council of Europe.

"Bilshist ekspertiv vvazhaiut obmezhennia dostupu do rosiiskykh Internet-resursiv stratehichno pravylnym rishenniam [A Majority of Experts Consider the Limitation of Access to Russian Internet Resources a Strategically Right Decision]," Detector Media, November 2, 2017, https://detector.media/infospace/article/131516/2017-11-02-bilshist-ekspertiv-vvazhayutobmezhennya-dostupu-do-rosiiskikh-internet-resursiv-strategichno-pravilnim-rishennyamopituvannya/. 
The increase of threats to Ukraine's informational security and the government's search for ways to resist them did not mean, however, that Ukrainian media reform was curtailed. On the contrary, it was already after the start of the Russian aggressionbetween 2014 and 2016 - that Ukraine managed to pass laws as vitally important for media independence as the law on public broadcasting, on the transparency of media ownership, and the privatization of state and municipal print media. However, after the post-Maidan breakthrough media reform has stalled again, and the lack of political will to complete it contributes not only to the maintenance of existing barriers for media independence in the country, but also to Ukraine's vulnerability to informational aggression from Russia. ${ }^{30}$

Differing from Ukraine, Hungary, for a long time since the communist breakdown in the late 1980s, was among the forerunners of democratic change. Its successful democratization included, among other things, efficient media reform: for example, according to Freedom House's press freedom annual surveys, in the period between 1994 and 2007 Hungary displayed a nine-point improvement in the level of media freedom (whereas Ukraine in the same period experienced a 9-point deterioration). Since 1998 and up to 2010 the Hungarian media were consistently ranked by Freedom House as "free" and its press freedom score was gradually approaching that of advanced democracies. ${ }^{31}$

30 A telling example is Ukraine's inability to cope with Russian propaganda at three Ukrainian information TV channels (NewsOne, 112 Ukraina and ZIK) belonging to the media holding Novosti, reportedly funded by Viktor Medvedchuk, a pro-Russian politician close to Vladimir Putin. The holding arose after the start of Russia's aggression in 2014. Its owner is Ukrainian MP Taras Kozak, a Viktor Medvedchuk ally. The rise of the holding and one of its channels (112 Ukraine) was conducted in breach of Ukraine's laws and antimonopoly regulations, and the content of the programs broadcasted by the holding's channels made the NTRBC sanction the latter through several warnings and fines for violating Ukrainian law and broadcast regulations (for details, see Georgy Chizhov, "Pro-Kremlin Influence in the Ukrainian Media," The Kremlin's Influence Quarterly 1 (2020): 66-70; Halyna Petrenko, "Shcho shukaly i znaishly deputaty u spravi pro kupivlu Kozakom NewsOne, 112 Ukraina i ZIK [What MPs Looked for in the Affair with the Kozak Purchase of NewsOne, 112 Ukraina, and ZIK, and What They Found]," Detector Media, April 18, 2020, accessed August 21, 2020, https://detector.media/infospace/ article/177236/2O2O-O5-18-shcho-shukali-i-znaishli-deputati-v-spravi-pro-kupivlyu-kozakomnewsone-112-ukraina-i-zik-mediapidsumki-1217-travnya-2020-roku/). Numerous lawsuits seeking to annul 112 Ukraina's licenses have been ongoing for several years. However, because of the NTRBC's weakness and lack of independence as well as the venality of Ukraine's unreformed courts the channels keep functioning and disseminating with impunity messages of Russian propaganda loaded with hate speech.

31 Peter Bajomi-Lazar, "The Consolidation of Media Freedom in Post-Communist Countries," in Finding the Right Place on the Map, eds. Karol Jakubowicz and Miklós Sükösd (Bristol: Intellect Books, 2008), 73-84. 
The situation deteriorated abruptly in 2010 when the populist right-wing Fidesz party, led by formerly liberal politician Viktor Orbán, won an overwhelming majority of seats in the Hungarian parliament. This majority allowed it to adopt a new constitution, which in turn made possible Orbán's concentration of power, weakening or removing checks and balances, undermining the rule of law, and effectively curtailing the media. ${ }^{32}$ Hungary's change in politics is far from the only case of what is currently described in Central and Eastern European regime change studies as "democratic backsliding," 33 "populist backlash," 34 or even "counter-revolution." 35 The analysis of its diverse causes lies beyond the scope of this study, ${ }^{36}$ which will focus only on one component of this change - the institutional one, in particular the change in the institutional environment for media freedom.

\section{Ukraine: Post-Communist Business-Political Elites as the Main Institution Builders}

In speaking about elite competition in Ukraine, it should be noted that unlike in CEE post-communist countries, no strong alternative to the communist party existed here before independence, thus allowing the communists to stay in power after the fall of communism. The communist party remained the largest and most popular political force in Ukraine during the first decade of independence, and no meaningful opposition arose to ensure quality party competition..$^{37}$ But, even more importantly, parties did not play a central role in Ukraine's institution-building. The main role in institution-building in the first post-independence years was played by a powerful

32 Miklos Bankuti, Gabor Halmai, and Kim Lane Scheppele, "Hungary's Illiberal Turn: Disabling the Constitution," Journal of Democracy 23.3 (2012): 138-46; Miklos Bankuti, Gabor Halmai, and Kim Lane Scheppele, "From Separation of Powers to Government without Checks: Hungary's Old and New Constitutions," in Constitution for a Disunited Nation: On Hungary's 2011 Fundamental Law, ed. Gabor Attila Toth (Budapest: CEU Press, 2012), 237-68. Bela Greskovits, “The Hollowing and Backsliding of Democracy in East Central Europe," Global Policy 6, supplement 1 (2015): 28-37. Jacques Rupnik, “From Democracy Fatigue to Populist Backlash," Journal of Democracy 18.4 (2007): 17-25. Jan Zielonka and Jacques Rupnik, "From Revolution to 'Counter-Revolution': Democracy in Central and Eastern Europe 3o Years On," Europe-Asia Studies 72.6 (2020): 1073-99.

36 Recent publications on the issue include: Jan Zielonka and Jacques Rupnik, "From Revolution to “Counter-Revolution”; Anna Grzymala-Busse, "How Populists Rule: The Consequences for Democratic Governance," Polity 51.4 (2019): 707-17; Bojan Bugarič, “The Populist Backlash against Europe: Why Only Alternative Economic and Social Policies Can Stop the Rise of Populism in Europe," in EU Law in Populist Times: Crises and Prospects, ed. Francesca Bignami (Cambridge: Cambridge University Press, 2020), 477-504.

37 Serhiy Kudelia and Taras Kuzio, "Nothing Personal: Explaining the Rise and Decline of Political Machines in Ukraine," Post-Soviet Affairs 31.3 (2015): 250-78. 
informal network of party and business elites, primarily the old nomenklatura and the rising entrepreneurial class, who acquired a taste for asset-stripping and manipulating the distortions of a hybrid economy soon after the fall of communism. ${ }^{38}$ As van Zon pointed out following Garnett, the pursuit of self-interest may have proven to be the most potent source of state-building in Ukraine. ${ }^{39}$

This situation did not change in principal during the next two decades of transformation. In Ukraine (like in some other non-Baltic post-Soviet states), "a stratum of rent-seeking political businessmen and/or neopatrimonial bureaucrats who use a combination of élan, politics, and property in order to achieve economic goals" was formed. ${ }^{40}$ It was the networks of these economic-political elites that structured political and economic processes in Ukraine and played the key role in determining the rules of "political games." ${ }^{41}$ As neither Ukraine's well-connected big businessmen (also referred to as oligarchs), nor rent-seeking public officers were interested in constraining their ability to extract state resources for private gain, they sabotaged the construction of discretion-limiting institutions. Describing the effects of Ukraine's state-building, to an overly significant extent driven by the elite's self-interest, Serhiy Kudelia used the words "incomplete state," pointing out that even after two decades of transformation Ukraine was still lacking the prerequisites for effective governance in a modern statean impersonal bureaucracy, the rule of law, and mechanisms for accountability. ${ }^{42}$ What is especially important for our analysis, focused on the institutional framework for the media, is that Ukraine's institution-building never resulted in the rise of independent courts and law enforcement agencies, which had multiple negative consequences for press freedom (this will be discussed in more detail below).

\section{The Institutional Environment for the Media in a FSU Hybrid Regime (Ukraine): Protracted and Unfinished Institution- Building}

As far as institutions directly related to the media are concerned, the best example of the unwillingness of Ukraine's institution builders to build discretion-limiting institutions in this realm is the long history of the creation of public broadcasting. Though the first attempt to adopt it happened in 1997, up to 2014, Ukraine, along with privately owned media, continued to have state-owned (and, correspondingly, state-

Serhiy Kudelia, "The Sources of Continuity and Change of Ukraine's Incomplete State," Communist and Post-Communist Studies 45·3-4 (2012): 419-23, https://doi.org/10.1016/j. postcomstud.2012.06.oo6.

39 Hans van Zon, The Political Economy of Independent Ukraine (London: Palgrave MacMillan, 2000), 44.

40 Oleksandr Fisun, "Rethinking Post-Soviet Politics from a Neopatrimonial Perspective,"

Demokratizatsiia 20.2 (2012): 91.

41 Fisun, "Rethinking Post-Soviet Politics," 91.

42 Kudelia, "Sources of Continuity," 417. 
controlled) television and radio. Ukrainian presidents with rather different political positions - Kuchma, Yushchenko, and Yanukovych - all tried to postpone the rise of the public broadcasting, which (in the conditions of oligarchal control over the main private television and radio channels) would have the capacity if not to limit the discretion of incumbents, to at least hold the latter to account publicly, exposing their unlawful acts. It was only in 2015, a year after the Ukraine's Revolution of Dignity and the rise of the new pro-European government, that the state broadcaster was finally transformed into the public one.

The next issue is the country's media regulator, the National Television and Radio Broadcasting Council (NTRBC), which can best be described as a winner-take-most institution. NTRBC members are appointed by Ukraine's president and by parliament, with some imbalance in favor of the president. ${ }^{43}$ According to an analysis by the Council of Europe, the process of the appointment of NTRBC members inevitably leads to appointments being made on the basis of political affiliations, with members of the National Council taking decisions on political grounds. ${ }^{44}$ Whereas the appointees from the president's quota are usually people loyal to him, those appointed by parliament are very often protégées of big oligarchic groups. The latter are interested in having their "representatives" in the media regulating body in order to safeguard and advance their media holdings. Thus, since its rise in 1994, the country's main broadcasting media regulator has not been an independent body but an instrument for the authorities, in particular Ukrainian presidents, to politically control or at least harass broadcasters. ${ }^{45}$ Unfortunately, the situation never improved after the fall of Viktor Yanukovych's autocracy in 2014: lawmakers did not manage to pass bills that would reinforce the NTRBC's independence, and the NTRBC remained dependent on political influence instead of serving the public interest. ${ }^{46}$

An additional problem with the National Television and Radio Broadcasting Council is that formal rules regulating its activity, most importantly - licensing regulations, are unclear, ambiguous, or in some cases even conflicting. In 2008 Ukrainian experts participating in the International Research \& Exchange Board's Media Sustainability Index panel even called legal provisions for licensing broadcasters

Taras Shevchenko, "How to Guarantee the Independence of the National Council of Ukraine in Charge of TV and Radio Broadcasting in the New Version of the Law of Ukraine 'On the National Council of Ukraine in Charge of TV and Radio Broadcasting?" The Kharkiv Human Rights Protection Group, April 8, 2004, accessed October 30, 2015, http://www.khpg.org/en/ index.php?id=1081416o13.

Eve Salomon and Karol Jakubowicz, "Analysis and Comments on Law of Ukraine Amending the Law of Ukraine on the National Television and Radio Broadcasting Council of Ukraine. Prepared for the Media Division of the Council of Europe at the Request of the Ukrainian Authorities," Council of Europe, 2007, accessed August 20, 2015, http://www.coe.int/t/dghl/ standardsetting/media/news/ATC M(2007)oo2_en.pdf. Ryabinska, Ukraine's Post-Communist Mass Media, 84-86. 
"one of the most shadowy of state regulations." 47 Since regulations concerning the licensing of broadcasters are unclear and ambiguous, it is hard to know what conditions must be met in order to obtain a license and exactly what actions are in violation of licensing requirements. This leads to a situation where practically every broadcasting company bends the regulations to some degree. Consequently, the regulatory power of the NTRBC is a convenient tool for the punishment of dissenting broadcasters. To use the political science terms introduced earlier, the design of Ukrainian legal provisions for licensing broadcasters enhances the discretionary power of the National Broadcasting Council (and the government as long as it controls the latter) to control the media.

The poor quality of the laws necessary to make an enabling legal environment for free and independent media in new democracies, ${ }^{48}$ or even the lack of some of them has been a consistent characteristic of Ukraine's media regulatory framework since independence. One of the significant deficiencies is the lack of enforceable regulations necessary to restrain the impact of Ukraine's business-political elites on the private sector of the media, which these elites have maintained since the early 2ooos. Ukraine's major private media belong to a handful of oligarchic groups, who concentrate in their hands both the country's nationwide TV and radio channels, private news agencies, the nationwide press and, in some cases, also the regional press, TV, and radio. ${ }^{49}$ Since 2010 these groups are also actively entering the market of online media. The dominance of oligarchic ownership of the media market is disadvantageous for the rise of a normal media market and healthy competition in the sector of Ukraine's private media. Oligarchic media owners - who obtain most of their income from other than media industries - are guided in their media holdings not so much by business logic but by the desire to impact politics and political decisions. Their media are often unprofitable and funded by money from the owners' other-than-media businesses. ${ }^{50}$ This leads to an overcrowded media market with little chance to survive for normal, unpoliticized, media businesses.

The problem is that for decades Ukraine's legislation do not put much constraint on the de facto monopolization of media ownership by oligarchic groups and on the detrimental influence of oligarchic media ownership both on the development of the media market and on the democratic performance of the media. Though Ukraine's media market was subject to anti-trust legislation, in practice media monopolies were not regulated. The government's anti-trust agency was unable to effectively combat

47 "Media Sustainability Index. Europe and Eurasia: Ukraine," 2018, 193.

48 A rather exhaustive list of laws necessary for an enabling legal environment for media independence is presented in: Monroe E. Price and Peter Krug, "The Enabling Environment for Free and Independent Media: Contribution to Transparent and Accountable Governance," Jacob Burns Institute for Advanced Legal Studies Working Paper no. 27 (December 2000), https://ssrn.com/abstract=245494 or http://dx.doi.org/10.2139/ssrn.245494. 
the monopolization of the media market. ${ }^{51}$ Ukrainian media moguls concealed their ownership of the media with the help of offshore entities and figureheads. In 2015, soon after the Euromaidan in 2013-2014, it seemed that the situation would improve. Ukrainian media-support organizations assisted by international NGOs and political actors managed to achieve the adoption of the long awaited Law on transparency in media ownership. The Law gave Ukrainian society the opportunity to obtain direct information on who owns what in the country's media market, and hence to judge the objectivity of the news. However, many other problems, especially those of market monopolization and unfair competition in Ukraine's media market remained unresolved. In particular, today Ukraine still lacks laws regulating media monopolies, and this further allows politically engaged businessmen to concentrate TV and radio channels in their hands. ${ }^{52}$ Media cross-ownership is not regulated either. ${ }^{53}$ The funding of the media remains non-transparent as well: to date the bill on the financial transparency of electronic media introduced in September 2019 has not been considered by parliament. 54

This all means that society in Ukraine has few instruments to restrict the discretion of the oligarchs to use media resources for their personal, political, and economic goals. Indeed, "in-house censorship" is one of the major constraints for journalistic independence in the country. As a survey among Ukrainian journalists conducted in June 2019 by the Democratic Initiatives Foundation indicated, "censorship by the owners of the media" is considered to be the main threat to press freedom and journalists' work by $70 \%$ of the journalists. ${ }^{55}$ This was the most frequently chosen answer for the survey's question about the main threats to press freedom and journalists' work.

"Media Sustainability Index. Europe and Eurasia: Ukraine," 2019, 206; see also Nataliia Dankova, "Deoliharkhizatsiia media yak vyklyk dlia novoho parlamentu [Media De-Oligarchization as a Challenge for the New Parliament]," Detector Media, July 17, 2017, https://detector.media/rinok/ article/169o71/2019-07-17-deoligarkhizatsiya-media-yak-viklik-dlya-novogo-parlamentu/.

Dankova, “Media De-Oligarchization"; "Media Sustainability Index. Europe and Eurasia: Ukraine," 2018, 10.

"Media Sustainability Index. Europe and Eurasia: Ukraine," 2018, 10.

Verkhovna Rada, Proekt Zakonu pro vnesennia zmin do Zakonu Ukrainy "Pro telebachennia i radiomovlennia" shchodo udoskonalennia mekhanizmiv zabezpechennia prozorosti vlasnosti ta finansuvannia audiovizualnykh (elektronnykh) zasobiv masovoi informatsii [The Bill on the Introduction of Amendments to the Law of Ukraine "ON TV and Radio" on Improving the Mechanisms of Audiovisual (Electronic) Media's Ownership and Funding Transparency], September 5, 2019, accessed August 12, 2020, http://w1.c1.rada.gov.ua/pls/zweb2/ webproc4__?id=\&pf3511=66701.

"Svoboda slova ta vyklyky dlia roboty zhurnalistiv v umovakh zbroinoho konfliktu v Ukraini [Freedom of Speech and the Challenges to the Work of Journalists Under the Conditions of Armed Conflict in Ukraine]," Fond Demokratychni Initsiatyvy, June 20, 2019, accessed July 25, 2019, https://dif.org.ua/article/svoboda-slova-ta-vikliki-dlya-roboti-zhurnalistiv-v-umovakhzbroynogo-konfliktu-v-ukraini. 
The other side of Ukraine's incomplete and flawed media legislation is the abundance of informal regulation of the media, especially in the realm of mediapolitics relationships. According to the above-mentioned study by Grzymala-Busse, the creation of lax and unenforced formal institutions (including, among others, poorly worded laws with loopholes, ambiguous language, and/or limited provisions for enforcement) is one of the ways to build discretion into these institutions. ${ }^{56}$ As far as the formal institutions in the media realm are concerned, studies in new Central and Eastern European democracies show that these institutions, specifically media regulating laws, too often happen to be flawed and unclear. ${ }^{57}$ This is often an effect of deliberate actions aimed at creating barriers for media independence and democratic performance. ${ }^{58}$ For example, hate speech or "personality protection" provisions may be designed to be (mis)used in the interests of political and economic elites who would seek to control or stifle critical media. ${ }^{59}$ According to Belakova and Tarlea, the intentionally vaguely formulated laws create a grey zone in which legislation can be interpreted in favor of particular interests. Their study showed that the latter is especially achievable when regulatory authorities that oversee the implementation of broadcasting and press legislation are weak. ${ }^{60}$

In Ukraine, the implementation of media laws is a weak point as well: the reports of media and human rights support organizations traditionally criticize the country for poor enforcement of media laws. According to the last report from the International Research and Exchange Board (IREX), in Ukraine "legal protections [for press freedom] are not properly enforced, and violations are not properly investigated." ${ }^{61}$ Poor enforcement of formal laws does not mean, however, that media and their relations with politics are not regulated at all. In fact, as some studies show, these relations are regulated in Ukraine, but informally. ${ }^{62}$

The list of informal institutions in the realm of media-politics relations in Ukraine includes, above all, the selective use of laws and administrative regulations to "discipline" the media, as well as coercion (often committed directly by law enforcement agencies). The agents responsible for the interpretation and implementation of media regulating laws in Ukraine - not only the media regulators but also courts and law enforcement

56 Grzymala-Busse, "Post-Communist Competition," 3.

57 Tehri Rantanen and Nikola Belakova, "Why it is Important to Study Media and Politics in New Democracies?" in Media and Politics in New Democracies: Europe in a Comparative Perspective, ed. Jan Zielonka (Oxford: Oxford University Press, 2015), 309.

$5^{8}$ Krygier, “Good, Bad, and 'Irritant," 125-27; Rantanen and Belakova, "Why it is Important," 3 og.

59 Belakova and Tarlea, How National Parliaments Legislate, 24.

6o Belakova and Tarlea, How National Parliaments Legislate, 19-20.

61 "Media Sustainability Index. Europe and Eurasia: Ukraine," 2018, 226.

62 Alexander Belyakov, “'Censorship by Money' on Freedom of Speech in Ukraine," Critique 37.4 (2009): 6o1-17; Katerina Tsetsura and Anastasia Grynko, "An Exploratory Study of the Media Transparency in Ukraine," Public Relations Journal 3.2 (2009): 1-21; Ryabinska, Ukraine's PostCommunist Mass Media, 75-81. 
agencies - are weak and lack independence. This results, on the one hand, in the selective use of some formal rules (such as, for example, license regulations or laws regulating media content) to punish critical and independent media. On the other hand, this causes the violation of the laws protecting media and journalists to often go unpunished. Significantly, in many cases those who violate these laws in Ukraine are the government and law enforcement entities. ${ }^{63}$ Attacks against journalists are a rather widespread practice in Ukraine, and the impunity of those who assault journalists creates a state of permanent tension among media professionals. ${ }^{64}$ It is no surprise that $41 \%$ of Ukrainian journalists consider physical threats or threats to life associated with journalistic activities to be the main threat to the freedom of speech and the work of journalists in Ukraine. ${ }^{65} 33 \%$ of them fear for their safety. ${ }^{6}$

A rather usual informal practice in media-politics relations in Ukraine consists of informal agreements between oligarchic media owners and the public administration, where media owners agree to ensure informational support to the government in exchange for privileges given to their key businesses, such as gas, metal, coal, energy, food processing, or banking. ${ }^{67}$ According to Ukraine's media experts, the government achieves control over private media primarily via informal agreements of this type.

Additionally, widespread in media daily routines is the informal practice of dzhynsa, or hidden political (less often, economic) advertising in exchange for illegal payment. ${ }^{68}$ Being most tangible in pre-electoral periods, it is also widespread in-between elections when it can rise to $40 \%$ of the content in local TV-newscasts. ${ }^{69}$ According to studies and reports from Ukrainian media watchdogs, hidden advertising in the media is not limited to sporadic orders for a propaganda article or video. Entire news packages and programs can be sold on Ukrainian television. ${ }^{70}$ What is troubling about

63 "Viktoriya Siumar: Freedom of Speech in Ukraine 2010-2012: The Main Trends," EU-Ukraine, May 15, 2012, accessed May 19, 2013, www.eu-ukraine.org/2012/o5/viktoriya-siumar-freedomofspeech-in-ukraine-2010-2012-the-main- trends; "Media Sustainability Index. Europe and Eurasia: Ukraine," 2015, International Research \& Exchanges Board, accessed September 7, 2016, https://www.irex.org/resource/media-sustainability-index-msi\#europe-eurasia.

64 "Media Sustainability Index. Europe and Eurasia: Ukraine," 2018.

65 "Svoboda slova."

66 "Svoboda slova."

67 "Vdaleke ot tsivilizatsii [Away from Civilization]," Mediasapiens, September 6, 2012, accessed August 14, 2013, http://osvita.mediasapiens.ua/ material/9967.

68 See, for example, Belyakov, “'Censorship by Money”; Nataliia Ligachova, "Nekotorye voprosy dzinsovedeniia [Some Issues of Dzhynsa Making]," Telekrytyka, March 26, 2008, accessed August 14, 2013, www.telekritika.ua/media-continent/authorcolumn/nl/2008-03-26/37372.

69 Natalka Sokolenko, "Parketni novyny ta loialnist do vlady zamist standartiv [Pro-Government Articles and Loyalty to the Authorities Instead of Journalism Standards]," Mediasapiens, April 3, 2013, accessed April 4, 2015, http://osvita.mediasapiens.ua/monitoring/regional_news/ parketni_novini_ta_loyalnist_do_vladi_zamist_standartiv/. 
dzhynsa is that it has become if not a normal, then at least a common way of making political news. Correspondingly, it often sets the templates for relationships between journalists and politicians involved in communicating political issues to the public. Ukraine's media watchdogs that monitor media content on a regular basis frequently raise the alarm that, especially during electoral campaigns, even newsworthy events involving candidates are covered for money. This indicates that the informal practice of concealed advertising has become a functioning pathology that structures the relationship between media and politics.

\section{The Institutional Environment for the Media in a Backsliding CEE Democracy (Hungary): Erosion of Discretion-Limiting Institutions}

When the conservative-nationalist Fidesz party won the first round of the parliamentary elections in Hungary and its chairman Viktor Orbán became Prime Minister in 2010, a series of restrictive press laws was pushed through parliament soon after the elections. First, the new laws established a new centralized media regulating agency, which is extensively controlled by the ruling party. The regulator, the National Media and Infocommunications Authority (NMHH), substituted two previous regulatory bodies, the National Radio and Television Commission and the National Media and Communication Authority. The power to appoint the president of the NMHH to a nine-year term was granted to the Prime Minister. ${ }^{71}$ The president of the NMHH has a wide range of powers. For example, he manages tendering and licensing for digital broadcasters. Moreover, he is vested with ministerial-level powers to issue decrees regarding license and spectrum fees. ${ }^{72} \mathrm{He}$ is also chair of the Media Council, a formally autonomous body within the $\mathrm{NMHH}$, which has the power to fine television and radio stations for unbalanced coverage, as well as to ban public subsidies to media outlets that are found guilty. ${ }^{73}$ Importantly, the Media Council consists of four members (not counting the above-mentioned chair) who are all appointed by parliament, in which Fidesz holds a supermajority. ${ }^{74}$ In terms of the Grzymala-Busse state-building perspective, the new media regulators created by Viktor Orbán's government in 2010 are a classic example of winner-take-all institutions. They give the Prime Minister and his Fidesz party extensive discretion in the access to such precious resources as broadcasting frequencies and licenses, well-paid positions in media authority, and,

$71 \quad$ "Freedom of the Press. Hungary," 2011.

72 Amy Brouillette, ed., Hungarian Media Laws in Europe: An Assessment of the Consistency of

Hungary's Media Laws with European Practices and Norms (Budapest: Center for Media and Communication Studies, 2012), accessed September 18, 2014, https://www.eui.eu/Documents/ General/DebatingtheHungarianConstitution/HungarianMediaLawsinEurope.pdf.

"Freedom of the Press. Hungary," 2011. 
indirectly, also airtime and the media's positive coverage of incumbents' performance in office (this point will be developed in more detail below).

Second, the new laws passed under Prime Minister Viktor Orbán in 2010 allowed his government to seize control over the public broadcaster. To start with, it obtained control over the finances of the public broadcaster: by creating a new fund for Hungary's public service media, the Media Service Support and Asset Management Fund (MTVA), and by giving the Fidesz-staffed Media Council the authority to manage it. Not only does the Media Council's chairperson (who is, as mentioned above, a Prime Ministerial appointee) appoint the MTVA's director general, deputy directors, the chairperson, and the four members of its supervisory board, the Media Council is also responsible for approving the Fund's annual plan and subsidy policy and for determining the rules governing how MTVA's assets can be used, managed, and accessed by the public media. ${ }^{75}$ In addition to control over the public broadcasters' funding, the Media Council also impacts its staffing: for example, the chairperson of the Media Council selects the nominees for directors of Hungary's public media outlets. ${ }^{76}$ The Media Council also appoints the chairperson and an additional member of the eight-member board of trustees of the Public Service Foundation, who in their turn, are responsible for appointing the directors of Hungary's public media outlets. ${ }^{77}$

If we consider the situation with the institutional changes in regard to the public broadcaster introduced by Viktor Orbán's government in terms of the state-building perspective, we may see that these changes to a large extent eroded the institution which, in principle, is supposed to limit the discretion of office holders in access to the airwaves - the institution of public broadcasting. By substantially modifying regulatory frameworks that should limit incumbents' discretionary power over the public media, such as, for example, regulations ensuring the broadcaster's financial independence, the institution (re)builders made it serve exactly the opposite purpose. Under the new system, the Prime Minister and the Fidesz Party obtained a set of mechanisms to control the public broadcaster and with their help transform it from what was initially designed to be a discretion-limiting institution into, if not a winner-take-all, then at least a winner-take-most institution compliant with the Fidesz party line.

The basic refashioning of the institutional environment for the media in Hungary was extraordinary in many senses. What is important for this analysis is that unlike previous changes of media regulations in CEE new democracies, which most often targeted the public media, the Hungarian redesign of media regulatory frameworks was also aimed at impacting privately owned media. A significant change for the media market was removing the article from Hungary's Constitution, which had previously banned information monopolies. ${ }^{78}$ It removed a substantial legal "safety

75 Brouillette, Hungarian Media Laws.

76 Brouillette, Hungarian Media Laws.

77 Brouillette, Hungarian Media Laws.

78 Karol Jakubowicz, "Analysis and Assessment of a Package of Hungarian Legislation and Draft

Legislation on Media and Telecommunications," OSCE, September 2010, accessed December 14, 
valve" preventing the consolidation of media ownership in pro-Fidesz hands. This launched the process of the rise and growth of powerful pro-government private media in Hungary: the pro-government private media were rising and expanding here since 2010 - through both acquisitions and the establishment of new outlets. ${ }^{79}$

The effect of the previously discussed winner-take-all institutions in Hungary, especially its new media regulating bodies, was enhanced by a set of newly introduced acts aimed at regulating media content. These acts were an integral part of the media legislation pushed through parliament by Fidesz. These content regulations include the "balanced" coverage obligation, obligations to respect the "constitutional order," provisions banning content that offends "public morality," and the extended regulation of hate speech. These content regulations are characterized, inter alia, by imprecise definitions and ambiguous language. According to analyses by media experts and international organizations, the acts' vague and overbroad language leaves too much room for their discretionary interpretation. ${ }^{80}$ This makes media regulating agenciesthe National Media and Infocommunications Authority and the Media Council, which are responsible for interpreting and enforcing media acts - a useful government tool to misuse content regulations to discipline critical media.

What was the effect of the Hungarian reconstruction of media regulatory frameworks for the interplay of media and political actors? According to international organizations monitoring press freedom in the world, they significantly influenced the behavior of journalists and other media employees. According to Freedom House yearly reports on the freedom of the press, since 2010 employees of Hungarian public and private media were repeatedly reporting to international watchdog organizations about growing self-censorship in the face of possible lawsuits, fines, or dismissal. ${ }^{81}$ The opportunity for incumbents to file these lawsuits against, and impose the fines on media outlets selectively (depending on an outlet's position - independent or "cooperative") was exactly what the discretion built into the reformed media regulations was aimed at.

\section{Agents of Institution-Building and Their Interests in CEE New Democracies}

Whatever negative assessments Hungary's backsliding in press freedom may cause, political scientists are far from explaining the changes introduced into media regulatory frameworks in Hungary (and some other new CEE democracies, for example, Poland) by the personal profiles of their particular political actors. At the same time, the researchers' explanatory framework does consider who the agents of institution-

2019, https://www.osce.org/fom/71218?download=true, 30-31.

79 "Freedom of the Press. Hungary," 2010-2017.

80 Jakubowicz, "Analysis and Assessment," 27-46; "Freedom of the Press. Hungary," 2011;

Brouillette, Hungarian Media Laws.

81 "Freedom of the Press. Hungary," 2011, 2013, 2016. 
building are in specific countries and what their incentives are in decisions regarding specific institutions.

In CEE new democracies, the main agents of institution-building are (parliamentary) political parties, the new democratic parties that came into power after the communist collapse. ${ }^{82}$ These parties usually were - and continue to bepoorly socially embedded and suffering from weak local structures. ${ }^{83}$ To make up for this weakness, politicians rely heavily on the media in electoral campaigning and beyond; for many Central and Eastern European politicians the media are virtually the only instrument for communication with the electorate. ${ }^{84}$ The possible incentive for the parties to seek control over media resources is thus the wish to build electoral support. Peter Bajomi-Lazar argues that there are several other purposes for which political office holders may want to exploit media resources. ${ }^{85}$ They may, for example, seek to extract such valuable resources as airtime, broadcasting frequencies, and wellpaid positions in media authority and public broadcasting with the aim to channel them to party supporters in order to reward the latter for past and future services. Other possible motivations may be to paralyze party rivals by means of limiting their visibility, cover up own corruption scandals, or compromise political rivals by means of smear campaigns. ${ }^{86}$

However strong political parties' incentives to build discretionary access to media resources into the media regulatory framework can be, this can be done only under certain political conditions. According to Grzymala-Busse, success in the building of discretion-limiting institutions in new CEE democracies depends on the robustness of competition between political elites. ${ }^{87}$ The same is true for success in extending one's discretion by means of sabotaging the rise of respective institutions, or by designing them to be politicized or lax and inefficient — this can be attained only when party competition is not robust. By robust competition Grzymala-Busse understands competition that "is characterized by an opposition that is clearly identifiable, plausible as a governing alternative, and vociferously critical, constantly monitoring and

82 Grzymala-Busse, "Post-Communist Competition," 8.

83 Jacques Rupnik and Jan Zielonka, “Introduction: The State of Democracy 20 Years On," East European Politics and Societies 27.1 (2012): 13-14, https://doi.org/10.1177/o888325412465110.

84 Peter Bajomi-Lazar, Party Colonisation of the Media in Central and Eastern Europe (Budapest: Central European University Press, 2014).

85 Peter Bajomi-Lazar, "Political Actors and the Colonisation of the Media," in Media and Politics in New Democracies: Europe in a Comparative Perspective, ed. Jan Zielonka (Oxford: Oxford University Press, 2015), 76.

86 Bajomi-Lazar, "Political Actors," 76; Vaclav Stetka, "From Multinationals to Business Tycoons: Media Ownership and Journalistic Autonomy in Central and Eastern Europe," The International Journal of Press/Politics 17.4 (2012); Vaclav Stetka, "The Rise of Oligarchs as Media Owners," in Media and Politics in New Democracies: Europe in a Comparative Perspective, ed. Jan Zielonka (Oxford: Oxford University Press, 2015), 93.

87 Grzymala-Busse, "Post-Communist Competition," 4; Grzymala-Busse, Rebuilding Leviathan, 1. 
censuring government action." 88 Grzymala-Busse's study demonstrates that in new CEE democracies where robust competition existed at the first stage of the transformation, institutions constraining the discretion of incumbents to exploit state institutions arose early, functioned autonomously, and could extensively investigate and limit the discretion of both politicians and bureaucrats. ${ }^{89}$ This is quite understandable as, in case they faced competition from strong opposition, parties had greater incentives to craft formal mutual guarantees against exploitation for each other and for the state. In countries where competition was weaker these institutional guarantees against the exploitation of state resources either failed to arise or, if created, were designed to be either explicitly politicized or enfeebled.90

If to extend this logic to the cases of radical state institutional reconstruction in backsliding European democracies, we can assume that attempts to erode existing discretion-limiting institutions have higher chances for success in a situation where political competition weakens. This was exactly the case with the Fidesz party's victory in Hungary's 2010 elections. At the time, support for its rival Socialist party declined after numerous scandals exposing rampant corruption in the party, giving way to serious popular support for Fidesz. A similar situation happened in another prominent case of press freedom setback in CEE, in Poland. Here the right-wing Law and Justice (PiS) party, which achieved a sweeping victory in the 2015 parliamentary elections, introduced amendments into the country's Broadcasting Act, which granted the government absolute power to control the country's public service media. This happened shortly after the party significantly overrode the rival Civic Platform party in the elections, becoming the first party in post-communist Poland to secure an outright majority in the lower chamber, the Sejm.

\section{Conclusion}

According to reports by international media support organizations, throughout 30 years of independence, Ukraine did not develop the kind of media landscape that a democratic society needs to form political opinion and provide its citizens with reliable information. ${ }^{91}$ Chronic problems plaguing Ukrainian media include the poor implementation of media related laws, impunity for crimes against the media, a preponderance of informal regulation of the media, the excessive concentration of media ownership in the hands of a handful of politically engaged business tycoons, and "in-house censorship," which makes journalists serve media owners rather than society. As this paper argues, these problems, as well as the non-linear trajectory of postcommunist media change in Ukraine - with successive sharp declines and increases

88 Grzymala-Busse, Rebuilding Leviathan, 11.

89 Grzymala-Busse, Rebuilding Leviathan, 85-86.

90 Grzymala-Busse, Rebuilding Leviathan, 104.

91 See, for example, the Freedom of the Press annual reports by Freedom House: https://

freedomhouse.org/report-types/freedom-press. 
in media freedom ratings that nonetheless never rose above "partly free" level-is difficult to explain by means of media-studies tools only. The theoretical tools of postcommunist media studies, embedded in the experiences of Western democracies, have limited capacity to explain media change in directions other than a democratic one. To overcome this obstacle, this paper proposed an interdisciplinary approach, applying advancements in political science studies of post-communist state-building in order to analyze the institutional environment for press freedom and its development in post-communist countries.

The proposed approach was used to analyze the development of the institutional environment for the media in two countries. One is Ukraine, which represents, in terms of post-communist state-building studies, the winner-takes-all system (where institutions were designed to protect the gains of early winners of elite competition). The other is Hungary, a country with a power-sharing system (with institutions providing guarantees for the political survival of losers of this competition), which, however, has undergone radical institutional reconstruction since 2010.

The analysis has shown the advantage of the way scholars of post-communist state-building approach state institutions: differing from media researchers, they analyze them without bracketing institution builders and their interests. Indeed, they see elite competition as the critical mechanism underpinning the creation of state institutions in post-communist societies, and the degree to which they compete with each other over access to governance as crucial in deciding not only what the new post-communist state institutions look like, but whose ends they serve. The key issue is the robustness of elite competition. When the governing parties face competition from vigorous opposition, they are more likely to build formal institutions that limit any one party's ability to gain private benefits from the state. In the case a strong opposition is lacking, there are high chances that the incumbents will create winnertake-all institutions, which privilege governing parties alone and avoid building formal constraints limiting any one party's discretionary access to state resources.

In this sense, the two cases examined in this paper, however different, have some similarities. In Ukraine, as in the majority of FSU countries, the process of state formation occurred in the conditions of a weak alternative or its absence to the communist party and its successors. Incumbents could therefore delay the creation of institutions necessary for the rise of a healthy media market and sabotage the rise of strong and independent media regulators. In the case of re-engineering mediarelated institutions in Orbán's Hungary after 2010, this re-engineering, disadvantageous for media independence, became possible due to Fidesz gaining an extraordinary parliamentary supermajority. Fidesz faced no opposition from its main rival party, which earlier discredited itself in numerous corruption scandals. Having the supermajority, Fidesz was left relatively free to change the constitution and remake the state.

This study helps to answer the question on the incentives of institution builders in both countries in shaping the institutional environment for the media. In both Ukraine and Hungary institution builders were mainly guided by the desire to build into the 
latter discretion for themselves to access media resources for private purposes and to limit effective restraints on their power. In the case of Hungary (as also in other Central and Eastern European post-communist countries that are parliamentary democracies), the wish to obtain discretionary access to media resources originates in the structural specificities of its party system, particularly poor social links, limited resources, and the practical monopoly of political parties over policy making and implementation (as compared to other possible participants in these processes such as presidents, trade unions, and non-governmental organizations). In post-communist winner-take-all countries where institution-building and implementation has never been in the hands of political parties themselves but in those of the business-political elites backing the parties, the willingness of the elites to possess discretionary power over the media is dictated by the same reason that makes them engage in politics - the search for access to state generated rents.

The applied theoretical frameworks also help to outline some characteristics of the institutional environment for the media that arise in result of institution-building aimed at privileging incumbents in access to media resources. These characteristics are: weak and non-autonomous media regulating authorities and flawed and inconsistent formal rules regulating media. One more feature is the lack of some important elements of the enabling institutional environment for media independence, such as anti-monopoly regulations or acts on access to public information. The formal regulatory framework with these characteristics has a number of disadvantages for media independence and pluralism. One of them is that it is conducive for the spread of informal institutions subversive for press freedom. The combination of imprecise (or lacking) formal rules and weak and politicized agencies responsible for the implementation of these rules creates a grey zone with uncertainty regarding the meaning and efficiency of formal rules. This creates incentives for the use of informal regulations that favor incumbent elites. Importantly, politicized media regulating authorities, by means of the selective enforcement of formal media regulations often de facto enforce informal rules. For example, media that violate the informal demand not to disclose the misdoings of incumbents may be punished by the latter (through government-controlled media regulators) in an indirect way, for allegedly breaking some formal rules. This may contribute not only to the spread, but also to the resilience of informal regulation in media-politics relations.

In Ukraine, the damage created by the unclear and flawed regulations is aggravated by the fact that not only media regulating authorities are controlled by the incumbents. Courts and law enforcement bodies - which possess the power to enforce a number of laws principally important for media independence (such as the law on the obstruction of journalists' work or the shield law) — also lack independence. In effect, the bodies tasked with defending journalists' rights often fail to fulfill this task and even violate these rights themselves.

In Ukraine, much of the discretionary access to media resources is carried out within private media belonging to oligarchs. This discretion is stipulated by limited and inefficient legal restraints for the concentration of media ownership in the 
hands of politicized owners as well as for the owners' interference in editorial policy. As a consequence, oligarchs have no legal barriers to use their media not only for advancing their own political and economic interests, but also for trading influence (which is manifested in the spread of concealed $d z h y n s a$ advertising). Unfortunately, the case of the developments in Hungarian media regulation since 2010 shows that illiberal governments in CEE may be interested in creating in their countries favorable conditions for discretionary access to media resources similar to those in winner-takeall systems. Indeed, in recent years we can observe the government-led takeover of the Hungarian media market where the Fidesz-led government and associated business figures acquired control over a large part of the Hungarian media landscape.

\section{Bibliography}

Bajomi-Lazar, Peter. "The Consolidation of Media Freedom in Post-Communist Countries." In Finding the Right Place on the Map: Central and Eastern European Media Change in a Global Perspective, edited by Karol Jakubowicz and Miklós Sükösd, 73-84. Bristol: Intellect Books, 2008.

Bajomi-Lazar, Peter. Party Colonisation of the Media in Central and Eastern Europe. Budapest: Central European University Press, 2014.

Bajomi-Lazar, Peter. "Political Actors and the Colonisation of the Media." In Media and Politics in New Democracies: Europe in a Comparative Perspective, edited by Jan Zielonka, 73-84. Oxford: Oxford University Press, 2015.

Bankuti, Miklos, Gabor Halmai, and Kim Lane Scheppele. "Hungary's Illiberal Turn: Disabling the Constitution." Journal of Democracy 23.3 (2012): 138-46.

Bankuti, Miklos, Gabor Halmai, and Kim Lane Scheppele. "From Separation of Powers to Government without Checks: Hungary's Old and New Constitutions." In Constitution for a Disunited Nation: On Hungary's 2011 Fundamental Law, edited by Gabor Attila Toth, 237-68. Budapest: CEU Press, 2012.

Belakova, Nikola and Silvana Tarlea. How National Parliaments Legislate the Media in CEE: The Adoption and Implementation of Media Legislation in the Czech Republic, Romania and Slovakia. Oxford, 2013. Accessed September 18, 2014. http://www. sze.hu/ smuk/Nyilvanossag_torvenyek_CEE/Szakirodalom/M\%C 3\%Agdia_ comparative_cikkek/mdcee\%2olegislative\%2oreport_ro-cz-sk_pv.pdf.

Belyakov, Alexander. “'Censorship by Money' on Freedom of Speech in Ukraine.” Critique 37.4 (2009): 6o1-17.

"Bilshist ekspertiv vvazhaiut obmezhennia dostupu do rosiiskykh Internet-resursiv stratehichno pravylnym rishenniam [A Majority of Experts Consider the Limitation of Access to Russian Internet Resources a Strategically Correct Decision]." Detector Media, November 2, 2017. https://detector.media/infospace/article/131516/2017-11o2-bilshist-ekspertiv-vvazhayut-obmezhennya-dostupu-do-rosiiskikh-internetresursiv-strategichno-pravilnim-rishennyam-opituvannya/. 
Brouillette, Amy, ed. Hungarian Media Laws in Europe: An Assessment of the Consistency of Hungary's Media Laws with European Practices and Norms. Budapest: Center for Media and Communication Studies, 2012. Accessed September 18, 2014. https://www.eui.eu/Documents/General/DebatingtheHungarianConstitution/ HungarianMediaLawsinEurope.pdf.

Bugarič, Bojan. "The Populist Backlash against Europe: Why Only Alternative Economic and Social Policies Can Stop the Rise of Populism in Europe." In EU Law in Populist Times: Crises and Prospects, edited by Francesca Bignami, 477-504. Cambridge: Cambridge University Press, 2020.

Carothers, Thomas. "The End of the Transition Paradigm." Journal of Democracy 13.1 (2002): $5^{-21}$. https://doi.org/10.1353/jod.2002.0003.

Chizhov, Georgy. "Pro-Kremlin Influence in the Ukrainian Media." The Kremlin's Influence Quarterly 1 (2020): 63-71.

Dankova, Natalia. "Deoliharkhizatsiia media yak vyklyk dlia novoho parlamentu [Media De-Oligarchization as a Challenge for the New Parliament]." Detector Media, July 17, 2017. https://detector.media/rinok/article/169o71/2019-07-17deoligarkhizatsiya-media-yak-viklik-dlya-novogo-parlamentu/.

Diamond, Larry. "Introduction: In Search of Consolidation." In Consolidating the Third Wave Democracies: Regional Challenges, edited by Larry Diamond, Marc F. Plattner, Yun-han Chu, and Hung-mao Tien, xxi-xxxvi. Baltimore; London: The Johns Hopkins University Press, 1997.

"Freedom in the World. Ukraine," 1992-2019. Freedom House. Accessed July 20, 2020, https://freedomhouse.org.

"Freedom of the Press. Hungary," 2010-2017. Freedom House. Accessed July 20, 2020. https://freedomhouse.org.

"Freedom of the Press. Ukraine," 1994-2017. Freedom House. Accessed July 20, 2020. https://freedomhouse.org.

Fisun, Oleksandr. "Rethinking Post-Soviet Politics from a Neopatrimonial Perspective." Demokratizatsiia 20.2 (2012): 87-96.

Ganev, Venelin. "Post-Communism as an Episode of State Building: A Reversed Tillyan Perspective." Communist and Post-Communist Studies 38.4 (2005): 425-45. https:// doi.org/10.1016/j.postcomstud.2005.09.008.

Ganev, Venelin. Preying on the State: The Transformation of Bulgaria after 1989. Ithaca: Cornell University Press, 2007.

Gelman, Vladimir. "Subversive Institutions, Informal Governance, and Contemporary Russian Politics." Communist and Post-Communist Studies 45·3-4 (2012): 295-303. https://doi.org/10.1016/j.postcomstud.2012.07.005.

Greskovits, Bela. "The Hollowing and Backsliding of Democracy in East Central Europe." Global Policy 6, supplement 1 (2015): 28-37.

Gross, Peter. "Between Reality and Dream: Eastern European Media Transition, Transformation, Consolidation, and Integration." East European Politics and Societies: and Cultures 18.1 (2004):110-31. https://doi.org/10.1177/o888325403259919. 
Gross, Peter. "Dances with Wolves: A Meditation on the Media and Political System in the European Union's Romania." In Finding the Right Place on the Map: Central and Eastern European Media Change in a Global Perspective, edited by Karol Jakubowicz and Miklós Sükösd, 125-43. Bristol, UK, and Chicago, IL: Intellect Books, 2008.

Gross, Peter. Entangled Evolutions: Media and Democratization in Eastern Europe. Washington, D.C.: Woodrow Wilson Center Press, 2002.

Grzymala-Busse, Anna, and Pauline Jones Luong. "Reconceptualizing the State: Lessons from Post-Communism." Politics \& Society 30.4 (2002): 529-54. https:// doi.org/10.1177/003232902237825.

Grzymala-Busse, Anna, and Pauline Jones Luong. "The Peculiarities of Post-Communist State Development: Institutional Consolidation and Elite Competition.” In The Oxford Handbook of Transformations of the State, edited by Stephan Leibfried, Evelyne Huber, Matthew Lange, Jonah D. Levy, Frank Nullmeier, 587-6o1. Oxford: Oxford University Press, 2015.

Grzymala-Busse, Anna. "How Populists Rule: The Consequences for Democratic Governance." Polity 51.4 (2019): 707-17.

Grzymala-Busse, Anna. Rebuilding Leviathan Party Competition and State Exploitation in Post-Communist Democracies. Cambridge: Cambridge University Press, 2007.

Grzymala-Busse, Anna. "Post-Communist Competition and State Development." Program on Central \& Eastern Europe Working Paper Series no. 59. 2004. http:// aei.pitt.edu/9274/1/Grzymala.pdf.

Helmke, Gretchen, and Steven Levitsky. "Informal Institutions and Comparative Politics: A Research Agenda." Perspectives on Politics 2.4 (2004): 725-40. https:// doi.org/10.1017/s1537592704040472.

Hrvatin, Sandra, and Brankica Petković. "Regional Overview." In Media Ownership and Its Impact on Media Independence and Pluralism, edited by Sandra Hrvatin and Brankica Petković, 10-38. Ljubljana: SEENMP and Peace Institute, 2004.

Jakubowicz, Karol. "Analysis and Assessment of a Package of Hungarian Legislation and Draft Legislation on Media and Telecommunications." OSCE, September 2010. Accessed December 14, 2019, https://www.osce.org/fom/71218?download=true.

Jakubowicz, Karol. "Post-communist Political Systems and Media Freedom and Independence." In Central and Eastern European Media in Comparative Perspective: Politics, Economy and Culture, edited by John Downey and Sabina Mihelj, 15-39. Burlington: Ashgate, 2012.

Krygier, Martin. “Good, Bad, and 'Irritant' Laws in New Democracies." In Media and Politics in New Democracies: Europe in a Comparative Perspective, edited by Jan Zielonka, 119-36. Oxford: Oxford University Press, 2015.

Kudelia, Serhiy, and Taras Kuzio. "Nothing Personal: Explaining the Rise and Decline of Political Machines in Ukraine." Post-Soviet Affairs 31.3 (2015): 250-78.

Kudelia, Serhiy. "The Sources of Continuity and Change of Ukraine's Incomplete State." Communist and Post-Communist Studies 45.3-4 (2012): 417-28. https://doi. org/10.1016/j.postcomstud.2012.06.oo6. 
Ligachova, Nataliia. "Nekotorye voprosy dzinsovedeniia [Some Issues of Dzhynsa Making]." Telekrytyka, March 26, 2008. Accessed August 14, 2013. www.telekritika. ua/media-continent/authorcolumn/nl/20o8-03-26/37372.

Mancini, Paolo. "The News Media Between Volatility and Hybridization." In Media and Politics in New Democracies: Europe in a Comparative Perspective, edited by Jan Zielonka, 25-37. Oxford: Oxford University Press, 2015.

"Media Sustainability Index. Europe and Eurasia: Ukraine," 2009, 2018, 2019.International Research \& Exchanges Board. Accessed August 13, 2020. https://www.irex.org/ resource/media-sustainability-index-msi\# europe-eurasia.

Petrenko, Halyna. "Shcho shukaly i znaishly deputaty u spravi pro kupivliu Kozakom. NewsOne, 112 Ukraina i ZIK [What MPs Looked for in the Affair with the Kozak Purchase of NewsOne, 112 Ukraina, and ZIK, and What They Found]." Detector Media, April 18, 202O. Accessed August 21, 2020. https://detector.media/infospace/ article/177236/2020-05-18-shcho-shukali-i-znaishli-deputati-v-spravi-prokupivlyu-kozakom-newsone-112-ukraina-i-zik-mediapidsumki-1217-travnya-2O2Oroku/.

Pfetsch, Barbara, and Katrin Voltmer. "Negotiating Control." The International Journal of Press/Politics 17.4 (2012): 388-406. https://doi.org/10.1177/1940161212449o84.

Price, Monroe E., and Peter F. Krug. "The Enabling Environment for Free and Independent Media." Jacob Burns Institute for Advanced Legal Studies Working Paper no. 0027. December 200o. https://doi.org/10.2139/ssrn.245494.

Rantanen, Tehri and Nikola Belakova. "Why it is Important to Study Media and Politics in New Democracies?" In Media and Politics in New Democracies: Europe in a Comparative Perspective, edited by Jan Zielonka, 305-20. Oxford: Oxford University Press, 2015.

Richter, Andrei. "The Partial Transition: Ukraine's Post-communist Media." In Media Reform:Democratizing the Media, Democratizing the State, edited by Monroe Price, Beata Rozumilowicz, and Stefan Verhulst, 133-54. London: Routledge, 2002.

Rupnik, Jacques, and Jan Zielonka. "Introduction: The State of Democracy 20 Years On." East European Politics and Societies 27.1 (2012): 3-25. https://doi. org/10.1177/0888325412465110.

Rupnik, Jacques. "From Democracy Fatigue to Populist Backlash." Journal of Democracy 18.4 (2007): 17-25.

Ryabinska, Natalya. "Media Capture in Post-Communist Ukraine." Problems of PostCommunism 61.2 (2014): 46-6o. https://doi.org/10.2753/ppc1075-8216610204.

Ryabinska, Natalya. Ukraine's Post-Communist Mass Media: Between Capture and Commercialization. Stuttgart: Ibidem-Verlag, 2017.

Salomon, Eve, and Karol Jakubowicz. "Analysis and Comments on Law of Ukraine Amending the Law of Ukraine on the National Television and Radio Broadcasting Council of Ukraine. Prepared for the Media Division of the Council of Europe at the Request of the Ukrainian Authorities." Council of Europe, 2007. Accessed August 20, 2015. http://www.coe.int/t/dghl/standardsetting/media/news/ATC M(2007)oo2_en.pdf. 
Shevchenko, Taras. "How to Guarantee the Independence of the National Council of Ukraine in Charge of TV and Radio Broadcasting in the New Version of the Law of Ukraine 'On the National Council of Ukraine in Charge of TV and Radio Broadcasting?" The Kharkiv Human Rights Protection Group, April 8, 2004. Accessed October 30, 2015. http://www.khpg.org/en/index.php?id=1081416o13.

Sokolenko, Natalka. "Parketni novyny ta loialnist do vlady zamist standartiv [ProGovernment Articles and Loyalty to the Authorities Instead of Journalism Standards]." Mediasapiens, April 3, 2013. Accessed April 4, 2015. http://osvita.me diasapiens.ua/monitoring/regional_news/parketni_novini_ta_loyalnist_do_vla di_zamist_standartiv/.

Stetka, Vaclav. "The Rise of Oligarchs as Media Owners." In Media and Politics in New Democracies: Europe in a Comparative Perspective, edited by Jan Zielonka, 85-98. Oxford: Oxford University Press, 2015.

Stetka, Vaclav. "From Multinationals to Business Tycoons: Media Ownership and Journalistic Autonomy in Central and Eastern Europe." The International Journal of Press/Politics 17.4 (2012): 433-56. https://doi.org/10.1177/1940161212452449.

"Svoboda slova ta vyklyky dlia roboty zhurnalistiv v umovakh zbroinoho konfliktu v Ukraini [Freedom of Speech and Challenges to the Work of Journalists Under the Conditions of Armed Conflict in Ukraine]." Fond Demokratychni initsiatyry, June 20, 2019. Accessed July 25, 2019. https://dif.org.ua/article/svoboda-slova-ta-viklikidlya-roboti-zhurnalistiv-v-umovakh-zbroynogo-konfliktu-v-ukraini.

Tsetsura, Katerina, and Anastasia Grynko. "An Exploratory Study of the Media Transparency in Ukraine." Public Relations Journal 3.2 (2009): 1-21.

Vachudova, Milada Anna. "The Transformation of the State in Eastern Europe." In The Oxford Handbook of Transformations of the State, edited by Stephan Leibfried, Evelyne Huber, Matthew Lange, Jonah D. Levy, Frank Nullmeier, 6o2-17. Oxford: Oxford University Press, 2015.

Van Zon, Hans. The Political Economy of Independent Ukraine. London: Palgrave MacMillan, 2000.

"Vdaleke ot tsivilizatsii [Away from Civilization]." Mediasapiens, September 6, 2012. Accessed August 14, 2013. http://osvita.mediasapiens.ua/ material/9967.

Verkhovna Rada. Proekt Zakonu pro vnesennia zmin do Zakonu Ukrainy "Pro telebachennia i radiomovlennia” shchodo udoskonalennia mekhanizmiv zabezpechennia prozorosti vlasnosti ta finansuvannia audiovizualnykh (elektronnykh) zasobiv masovoi informatsii [The Bill on the Introduction of Amendments to the Law of Ukraine "On TV and Radio" on Improving the Mechanisms of Audiovisual (Electronic) Media Ownership and Funding Transparency]. September 5, 2019. Accessed August 12, 2020. http://w1.c1.rada. gov.ua/pls/zweb2/webproc4_1?id=\&pf3511=66701.

"Viktoriya Siumar: Freedom of Speech in Ukraine 2010-2012: The Main Trends." EUUkraine, May 15, 2012. Accessed May 19, 2013. www.eu-ukraine.org/2012/05/ viktoriya-siumar-freedom-ofspeech-in-ukraine-2010-2012-the-main- trends. 
Zielonka, Jan, and Jacques Rupnik. "From Revolution to 'Counter-Revolution': Democracy in Central and Eastern Europe 30 Years On.” Europe-Asia Studies 72.6 (2020): 1073-99.

Zimmer, Kerstin. "Formal Institutions and Informal Politics in Ukraine." In Formal Institutions and Informal Politics in Central and Eastern Europe: Hungary, Poland, Russia and Ukraine, edited by Gerd Meyer, 267-303. Opladen; Farmington Hills: Barbara Budrich, 2008.

\section{Div}

Natalya Ryabinska is an Associate Professor at Collegium Civitas in Warsaw. Her research focuses on media systems in post-communist Europe and Eurasia, media transformations in hybrid regimes, media and democracy, political and international communication, new media. In 2017 she published a book entitled Ukraine's PostCommunist Mass Media: Between Capture and Commercialization. 